Journal of Educational Method and Technology Vol. 2 No. 3, Desember 2019

P-ISSN 2622-8459 E-ISSN 2622-8467

http://ejournal.unima.ac.id/index.php/jemtec

\title{
Enhancing Students' Speaking Ability Through Small Group Discussion Technique to the Firts Year Students of SMA Negeri 1 Ratahan
}

T Mogea ${ }^{1}$

${ }^{1}$ Universitas Negeri Manado, Indonesia

corresponding author: ${ }^{1}$ tinimogea@unima.ac.id

\begin{abstract}
This research in intended to find out the effectiveness of small group discussion technique in improving the students's speaking ability. It was conducted at SMA Negeri 1 Ratahan in which one class of the first-year students of the school was the sample. The data of the research were obtained by using test in the form of pre-test and posttest. The result showed that the scores of the post-test were higher than that of the pre-test. The mean of the post-test is 8.2 and the mean of the pre-test is 6.7. Teaching speaking skill by using small group discussion technique can improve the students' ability in speaking. Small group discussion technique can give the students opportunity to practice their language. In small group discussion, they can express their ideas and thought freely. It will be better for English teacher to vary the techniques of teaching to avoid boredom that might appear to the students.
\end{abstract}

Keywords: Speaking abiliy; Technique; Small group discussion

\section{Introduction}

To learn a language is to learn how to use it, how to respond to situation and how to understand what others say. We all know that the function of language is a tool of sommunication or something in connection with listening is a tool of communication or something in connection with listening and speaking. Listening is for the purpose of compthension which is to understand what other say; speaking is for the purpose of expression, which is the use of language in order to express thoughts and feeluings, including responding or reacting to the spoken words.

English takes up a very important position in almost every walk of life: business, commerce, academic field, tourism, etc. It has been claimed as the first foreign languge in Indonesia.So it is included in the curriculum as the foreign language to be taught in school. In learning English there are four skills that should be mastered by the students in ordeeer to use English well. They are listening, speaking, reading and writing. And speaking is the first requirement in practicing a language. Lado (1977:240) states: "Speaking is described as the ability to express oneself in life situation, or the ability to report acts or situation in precise words, or the ability to conceive or to express a sequence of ideas fluently".

Based on the statement above we can say that by speaking the students can express thier ideas and opinion. But unfortunately most of the students were not able 
Journal of Educational Method and Technology Vol. 2 No. 3, Desember 2019

P-ISSN 2622-8459 E-ISSN 2622-8467

http://ejournal.unima.ac.id/index.php/jemtec

to communicate in English. It is because they were afraid to make mistakes or they were scared to their teacher.

\section{Review of Literature \\ Teaching and Learning}

Teaching and learninf are two important aspects that cannot be separated. These activities involve both teachers and studnts. Brown (1979:7) stated that "Teaching is showing or helping someone to learn how to do something providing with knowledge causing to know or to understand." From the quotation, we can say that teaching is a process. It includes all activities done by the teacher in order to create a good situation in which learning process may occur.

Teaching may be said as an activity to help students develop themselves and be able to adapt in the group where they belong. As the result of teaching, the students should be able to interact in their group. They learn to think, feel, and act in harmony through social and cultural values shared by the group of which they belong.

Learning is considered a process so everyone has to learn gradually according to their age. Hilgard in Nasution (1995:35) stated that. "Learning is a process by which an activity originates or is changed through training procedure as distinguished from changes by factor not attributable to training." People learn everything from their encironment, people around them of from formal and informal eucation. By learning they will have some experience as well as increasing their knowledge. In learning, students are expexted to be changed from knowing nothing to knowing something.

The succes of learning depends on several factors: the teacher, the students, curriculum, the material, and the method. These factors are related each other. But the most important factor is the teacher. The teacher must be able to create a warm and friendly atmosphre so in teaching English as a foreign language, a teacher has to be creative to manage the classroom, so that the aim of teaching can be achieved.

\section{Speaking Ability}

Speaking skill is one of the four language skills that seem to be a priority on. Since language is means of communication between individuals in the spoken form. "Speaking ability describe as the ability to express oneselfin life siuation, or the ability to report acts or situation in precise words; or the ability to conceive or to express a sequence of ideas fluency" (Lado, 1977:240). This statement means that speaking is very important for human beings to express ideas, feelings, and report situaion to other people.

\section{Small Group Discussion}

"A good way zto give students opportunities to speak English is to schedule them in small group discussion" (Lubis, 1988:55). Small group discussion is a technique teaching in which the teacher divides the class into small groups. Each group may consist of four to five stiudents. In small groups, the students sit together facing one another and talk freely. This situation creates free communication in which the students use their language freely in the classroom without feeling shy. 
Journal of Educational Method and Technology Vol. 2 No. 3, Desember 2019

P-ISSN 2622-8459 E-ISSN 2622-8467

http://ejournal.unima.ac.id/index.php/jemtec

In small group discussion, all members of the group are involved. Nutta (1982:162), "By divising the class into groups you make it possible for the students ti help one another. In groups, all members are active and the communication takes place. The learning that occurs by working together is greater than the individuals alone." Based on the statelemt above we can conclude that, by groups that have a good motivation in learning process. They can help ne another. Working together can produce a better result.

Clark and Starr (1981:25) stated that "there is no best metod of teaching or any method that will suit all occasions. Every method of teaching has its own advantages and disadvantages, so does the method". According to Hopson and Scally (1981:115) there are some advantages and diadvantages of small group discussion.

1) Adantages of teaching learning in small group

a. It can develoop social skils through social interaction

b. It can increase self-awareness as individuas are encouraged to express opinions and related their own ideas, preferences, and experiences and receie feedback or get reactions from others.

c. It can very supportive and encouraging for individuals to feel accepted by other group members.

d. It can increase self-confidence to hear other people have similar concerns and anxieties.

e. The use of small group with their emphasis on the value of everybody's contribution can convey that each of us has something to teach, and also each of us can direct our own learning by formulating our own ideas and by analysing accpeting or rejecting the view we hear.

2) Disadvantages of teaching /learning in small groups

a. it can mean less appatent control by the teaher andmo need for students responsilities.

b. it can be more difficult to evaluate the learning than in those lesson in which students can be given a written test and their answer mared right or wrong.

\section{Organizing Small Group Discussion}

In conducting a small group discussion, there are some aspects that should be taken into account senriously. These aspects are students' factor, the classroom, and the teacher's role. In guiding the small group discussion, the teacher should know how to organize the class well.

\section{Students' Role}

Normally, in a goup discussion there is a leader and the member of the group. To make the discussion run well and successful, each student should know their roles in a group.

1) The Role of the Group Leader

A group work requires a group leader. This intended to get someone to take responsible in the group. The role of the group leader according to Clark and Starr (1981:187) as the folllowing:

a. Introducing the topic: what is to be discussed?

b. Keeping the discussion moving on the track 
Journal of Educational Method and Technology Vol. 2 No. 3, Desember 2019

P-ISSN 2622-8459 E-ISSN 2622-8467

http://ejournal.unima.ac.id/index.php/jemtec

c. Summarizing the result of the group

d. Suggesting and guiding the conversation

In soite of the importance of the leadership role, discussion leader should not dominate the discussion, for a discussion should be an opportunity for participants to share ideas.

2) The Role of the Group Members

According to Clarck ans Starr (1981:186), the following are very important to be considered:
a. Initiating
b. Giving and asking for information
c. Giving and asking the reaction
d. Summarizing

\section{3) Teacher's Role}

In teaching speaking to the students, the teher has some roles as:

a. Give clear instruction about when to start, what to do and when to stop.

b. Give clear define task

c. Set up routine, so that students accept the idea of working in groups and know exactly what to do.

Most important, during the discussion the teacher shoukd assume the role of a consultant who is always available as a resoure person or advisor forwhatever contngency might arise. In discussion, the teacher act as the servant rather the master of the group (Clark and Starr, 1981:189).

\section{Grouping}

Dividing a large class into small groups can be done by many ways. Rory McGreat (1989:17) states that "Students can be divided according to many criteria. The most random sample, ability, friendship, and mixed-ability.

In ability grouping, students are grouped according to their ability levels. Frienship grouping is a way of grouping students that they are free to make their own groups. They will gather their friends whohave a close relation with them.

Another way of grouping is mixed-ability. Mixed-ability is a set up by thteacher in order to avoid the superior and the inferior groups. Besides, it also intends to get the effect that the weak studebnts can learn a great deal fgrom better students when they work together.

Mixed-ability grouping is preferred because it gathers good and weak students staying in one group.

\section{Reporting Group work}

When groups' members have inished their discussion, they should elect a spokesman to report on the group collective thoughts to the entire class. Then the teacher as a leader, discussions the result together with the class. This activity ends after the groups discuss the result and have the solutions which satisfy the students as well as the teacher. 
Journal of Educational Method and Technology Vol. 2 No. 3, Desember 2019

P-ISSN 2622-8459 E-ISSN 2622-8467

http://ejournal.unima.ac.id/index.php/jemtec

\section{Correction and Feedback}

Correction and feedback are gven at the end of session. The students sit like before not in groups anymore. According to the Random House Dictionary of English Language (1964:301), "correction is something that is substituted or proposed for what is wrong".

According to Cobuis (1987:524). "feedback consists of comment and information about something that someone has done." Feedback is essential in helping groups and group members learn more about how they operate and about themselves individually. Hopsonn and Scally (1981:181) states that feedback has to be given skillfully. This will more likely be achieved if the folllowing rules are observed.

1) Feeback should be offered rather that imposed

2) Feedback should be specific and should eer to features or behaviors that can be changed.

3) Feedback should emphasize the positive rather thath the negative

4) If negative is given it should include a positive suggestion

5) The person giving then feedback should take responsibility for it and the feedback should be checked out with others.

Through feedback grouos and individuals should take responsibility for it and the feedback should be checked out with others. Through feedback, grouos and individuals are helped towards greater awareness of themselves and it should therefore become an integral part of group work.

\section{Coping with Difficult Members}

Sometimes the discussion does not run well. This case can be influenced by some factors; one of them is student factor. Each student has his own characteristics since they might come from different background. Hopson and Scally in their book "Lifeskill Teaching (1981) give some ways to cope with difficult members of the group:

1) Silent

a. Have equal/shared time exercises.

b. Pair with friend or place in group who will provide support and encouragement

c. Give preparation time so that he has time to think and work out something to say

d. Support any contribution as an encouragement

2) Shy

a. Place with friends

b. Avoid over attention, but encourage by supporting Contribution.

c. Work one-to-one afterwards, encouraging the person to experiment with making small contributions to begin with.

d. Allow time for person to develop confidence.

3) Too talkative or dominant

a. Avoid eye contact

b. Share time in group

c. Give a task, like writing to reduce talking time

4) Bored, withdrawn 
Journal of Educational Method and Technology Vol. 2 No. 3, Desember 2019

P-ISSN 2622-8459 E-ISSN 2622-8467

http://ejournal.unima.ac.id/index.php/jemtec

a. Introduce participatory exercise or procedure.

b. Give feedback. Checked out feelings and reasons.

c. Pair or groups with friends.

5) The 'clown'-causes disruption

a. Confront the behavior and its through inapropriate use of humor effect. Be specific about how the person might behave more appropriately.

b. Place in group that will not reinforce the behavior by providing an audience

6) Less articulate

a. Allow time to gain confidence. Build confidence by encouragement and suportive behavior. Encourage group to do this

b. Give time to prepare. Help with preparation. Use shorter session to reduce pressure.

7) 'Distracter'

a. Give feedbak on behavior and its effect, and indicate nspecific changes that the person might make in behavior.

b. Place in group that is unlikely to reinforce or welcome distraction.

c. Provide alternative to presence in group.

\section{The Application of Small Group Discussion in Teaching Speaking}

Normally in a class there are good sudents and weak students. There are some faster students and there are also slower students. To solve this problem, teacher can use small group discussion technique. It is better for a teacher to choose mixedability grouping to gather good and weak students, because in groups the students can help one another and they do not have to feel shy since they just interact with their friends. This technique provides an opportunity for the students to use their English.

Steps in conducting the group discussion technique according to Lubis (1988:55) are stated below:

1) Devide the class into groups of five to six people.

2) Give each group discussion topic.

3) Have one student in each group write down the important points as they emerge from discussion by group members.

4) Allows the group to discuss their respective topics at least ten minutes.

5) When group members have finished their discussion, they should elect a spokesman to report on the group collective thoughts to the entire class.

6) After she/he gives a short presentation, class members should ask question.

7) Follow the same procedure with the remaining groups until all grouped have given their presentation.

\section{Results and Discussion \\ Research Design}

In doing this research, the writer sed qualitative research through preexperimental design with one group pre-testand post-test design. The writer used only one class. Pre-test was given before treatment and post-test was given after treatment. 
According to Hatch and farhaady (1982:20), "one group pre-test and post-test design similar to the one-shot case study. The difference is that a pre-test is given before instruction (or treatment) begins. So there are two tests: T1 is pre-test and T2 post-test, $\mathrm{X}$ is used to symbolize the treatment in the following representation of the design.

Table 1. Research Design

\begin{tabular}{|l|l|l|}
\hline Pre-test & Treatment & Post-test \\
\hline T1 & $\mathrm{X}$ & $\mathrm{T} 2$ \\
\hline
\end{tabular}

\section{Population and Sample Population}

Gay (1981:86) statest that "A population is the group of interest to the researcher, the group to which she or he would like the result of the study to be generalizable."

The population of this research consists of the whole class of the first year of SMA Nageri 1 Ratahan. The writer limits the popluation only to the first year students.

\section{Sample}

Gay (1981:85) states that "Sample is the individuals represent the larger group which they were selected".

The sample was taken one class from population. The writer chooses one class, IA that consist of 30 students to be the sample of this research.

\section{Research Instrument}

The instrument of this research is test. The test was in the form of oral test. The tests are called pre-tets and post-test in the form of oral test. Both the tests were intended to see the result of students in speaking ability.

To evaluate the students' speaking ability, there are four scales scoring system that has been developed by Rennate Schulz. They are: ffluency, comorehensibility, amount of communication and quality of communication. The levels of this scale were defined as follows:

1) Speech is so halting and fragmentary that conversation is virtually impossible

2) Speech is very slow and uneven expect for short or routine sentences

3) Speech is frequently hesitant and jerky; sentences may be left uncompleted

4) Speech is occasionally hesitant dan with some unevenness caused by rephrasing and grouping for words

5) Speech is effirtless and smooth, but perceptibly non-native in speeach and evenness

6) Speech is on all professional and general topics as effortless and smooth as a native speaker's

\section{Comprehensibility}

1) No comprehension, the examiner could not understand a thing the students said 
Journal of Educational Method and Technology Vol. 2 No. 3, Desember 2019

P-ISSN 2622-8459 E-ISSN 2622-8467

http://ejournal.unima.ac.id/index.php/jemtec

2) The examiner comprehended small bits and pieces, isolated words

3) The examiner comprehended some words, clusters and phrases

4) The examiner comprehended short simple sentences

5) The examiner comprehended most of what the students said

6) The examiner comprehended all of what the student said

\section{Amount of Communication}

1) Virtually no relevant was conveyed by the student

2) Very little relevantt information was conveyed by the student

3) Some relevant information was conveyed by the student

4) A fair amount of relevant information was conveyed by the student

5) Most relevant information was conveyed by the student

6) All relevant information was conveyed by the student

\section{Quality of Communication}

1) No utterance rendered correctly

2) Very few utterances rebdered structurally correct

3) Some utterances rendered correctly, by many structural problems remain

4) Many correct utterances, but some problems remained with structure

5) Most utterances rendered correctly, only minor problems with structure

6) All utterances rendered correctly.

\section{Data Analysis}

In analyzing the data, the writer use score formula. The data would be presented in frequency distribution. Then, the score of the test would be presented in frequency polygon.

\section{Data Analysis}

The obtained data are put into the table of frequency distribution. And the compulation of mean score formula is done to see whether the hypothesis is rejected or not. To present the data on the frequency distribution, the following is scores of the students in the pre-test (test 1) and post-test (test 2).

Table 1. The scores of the students in pre-test and post-test

Table 2. Frequency distribution matrix of pre-test

Table 3. Frequency distribution matrix of post-test

Table 4. Computation of mean (x) and standard dviation (S) of pre-test score

Table 5. Computation of mean (x) and standard deviation (S) of post-test score

Figure 1. Frequency polygon of pre-test

Figire 2. Frequency polygon of post-test

Figure 3. Frequency polygon of pre-test and post-test 
Journal of Educational Method and Technology Vol. 2 No. 3, Desember 2019

P-ISSN 2622-8459 E-ISSN 2622-8467

http://ejournal.unima.ac.id/index.php/jemtec

Table 1. The scores of students in pre-test and post-test

\begin{tabular}{|c|c|c|}
\hline $\mathrm{N}$ & T1 & $\mathrm{T} 2$ \\
\hline 1 & 6 & 7 \\
\hline 2 & 6 & 7 \\
\hline 3 & 7 & 8 \\
\hline 4 & 6 & 8 \\
\hline 5 & 8 & 9 \\
\hline 6 & 7 & 9 \\
\hline 7 & 6 & 8 \\
\hline 8 & 7 & 9 \\
\hline 9 & 7 & 9 \\
\hline 10 & 6 & 7 \\
\hline 11 & 6 & 8 \\
\hline 12 & 7 & 8 \\
\hline 13 & 6 & 7 \\
\hline 14 & 6 & 8 \\
\hline 15 & 6 & 8 \\
\hline 16 & 7 & 8 \\
\hline 17 & 6 & 8 \\
\hline 18 & 6 & 7 \\
\hline 19 & 8 & 9 \\
\hline 20 & 8 & 9 \\
\hline 21 & 6 & 8 \\
\hline 22 & 6 & 9 \\
\hline 23 & 6 & 8 \\
\hline 24 & 7 & 8 \\
\hline 25 & 7 & 8 \\
\hline 26 & 7 & 9 \\
\hline 27 & 8 & 9 \\
\hline 28 & 7 & 8 \\
\hline 29 & 8 & 9 \\
\hline 30 & 7 & 9 \\
\hline$\sum$ & 201 & 246 \\
\hline
\end{tabular}

From the table 1, there were thirty (30) students tok part in the test, of these thirty (30) students, there was one (1) student who got increased by three (3) point, there were thirteen (13) students who got increased by two point, and there sixteen (16) students who got increased by one (1) point).

So, the result of this research shows that it is effectiive to increase the students' ability in speaking because the score of post-test were higher than those of pre-test. In other words, when the technique was applied in teaching speaking the scores increased. 
Journal of Educational Method and Technology Vol. 2 No. 3, Desember 2019

P-ISSN 2622-8459 E-ISSN 2622-8467

http://ejournal.unima.ac.id/index.php/jemtec

Table 2. Frequency distribution matrix of pre-test

\begin{tabular}{|c|c|c|c|c|c|}
\hline Score & Tally & Frequency & $\begin{array}{l}\text { Cumulative } \\
\text { Frequency }\end{array}$ & $\begin{array}{l}\text { Cumulative } \\
\text { Proportion }\end{array}$ & $\begin{array}{l}\text { Cumulative } \\
\text { Percentage }\end{array}$ \\
\hline 8 & $1+x$ & 15 & 30 & 1 & 100 \\
\hline 7 & IXI NXII & 11 & 25 & 0,83 & 83 \\
\hline 6 & $|N| N|N| / I$ & 14 & 14 & 0,46 & 46 \\
\hline
\end{tabular}

Table 2 shows that there were 30 students took part in pre-test, of these students the highest point was eight (8) achieved by five (5) students, the lowest point was (6) acieved by fourteen (14) students, and seven (7) achieved by elevan (11) students.

Table 3. Frequency Distribution matrix of post-test

\begin{tabular}{|c|c|c|c|c|c|}
\hline Score & Tally & Frequency & $\begin{array}{l}\text { Cumulative } \\
\text { Frequency }\end{array}$ & $\begin{array}{l}\text { Cumulative } \\
\text { Proportion }\end{array}$ & $\begin{array}{l}\text { Cumulative } \\
\text { Percentage }\end{array}$ \\
\hline 8 & $1 \times 1 \times 1$ & 11 & 30 & 1 & 100 \\
\hline 7 & $\| / X / N \mid / I$ & 14 & 19 & 0,63 & 63 \\
\hline 6 & $N \mid$ & 5 & 5 & 0,16 & 16 \\
\hline
\end{tabular}

Table 3 shows that of thirty (30) students involve in post-test eleven (11) students got nine (9), fourtheen (14) students got eight (8), and five (5) students gor seven (7).

Table 4. Computation of mean ( $x$ ) and standard deviation (s) of pre-test

\begin{tabular}{|l|l|l|}
\hline $\mathrm{N}$ & $\mathrm{T} 1$ & $\mathrm{~T} 2$ \\
\hline 1 & 6 & 36 \\
\hline 2 & 6 & 36 \\
\hline 3 & 7 & 49 \\
\hline 4 & 6 & 36 \\
\hline 5 & 8 & 64 \\
\hline 6 & 7 & 49 \\
\hline 7 & 6 & 36 \\
\hline 8 & 7 & 49 \\
\hline 9 & 7 & 49 \\
\hline 10 & 6 & 36 \\
\hline 11 & 6 & 36 \\
\hline 12 & 7 & 49 \\
\hline
\end{tabular}


Journal of Educational Method and Technology Vol. 2 No. 3, Desember 2019

P-ISSN 2622-8459 E-ISSN 2622-8467

http://ejournal.unima.ac.id/index.php/jemtec

\begin{tabular}{|l|l|l|}
\hline $\mathrm{N}$ & $\mathrm{T} 1$ & $\mathrm{~T} 2$ \\
\hline 13 & 6 & 36 \\
\hline 14 & 6 & 36 \\
\hline 15 & 6 & 36 \\
\hline 16 & 7 & 49 \\
\hline 17 & 6 & 36 \\
\hline 18 & 6 & 36 \\
\hline 19 & 8 & 64 \\
\hline 20 & 8 & 64 \\
\hline 21 & 6 & 36 \\
\hline 22 & 6 & 36 \\
\hline 23 & 6 & 36 \\
\hline 24 & 7 & 49 \\
\hline 25 & 7 & 49 \\
\hline 26 & 7 & 49 \\
\hline 27 & 8 & 64 \\
\hline 28 & 7 & 49 \\
\hline 29 & 8 & 64 \\
\hline 30 & 7 & 49 \\
\hline$\sum$ & 201 & 1363 \\
\hline
\end{tabular}

Standard Deviation (S1)

$$
\begin{aligned}
& S 1=\sqrt{\frac{n \cdot \Sigma X^{2}-(\Sigma X)^{2}}{n(n-1)}} \\
& S 1=\sqrt{\frac{30.1363-(201)^{2}}{30(30-1)}} \\
& S 1=\sqrt{\frac{40890-40401}{30.29}} \\
& S 1=\sqrt{\frac{489}{870}} \\
& S 1=\sqrt{0,56} \\
& S 1=0.75
\end{aligned}
$$


Journal of Educational Method and Technology Vol. 2 No. 3, Desember 2019

P-ISSN 2622-8459 E-ISSN 2622-8467

http://ejournal.unima.ac.id/index.php/jemtec

Table 5. Computation of Mean and Standard Deviation

\begin{tabular}{|c|c|c|}
\hline $\mathrm{N}$ & T1 & $\mathrm{T} 2$ \\
\hline 1 & 7 & 49 \\
\hline 2 & 7 & 49 \\
\hline 3 & 8 & 64 \\
\hline 4 & 8 & 64 \\
\hline 5 & 9 & 81 \\
\hline 6 & 9 & 81 \\
\hline 7 & 8 & 64 \\
\hline 8 & 9 & 81 \\
\hline 9 & 9 & 81 \\
\hline 10 & 7 & 49 \\
\hline 11 & 8 & 64 \\
\hline 12 & 8 & 64 \\
\hline 13 & 7 & 49 \\
\hline 14 & 8 & 64 \\
\hline 15 & 8 & 64 \\
\hline 16 & 8 & 64 \\
\hline 17 & 8 & 64 \\
\hline 18 & 7 & 49 \\
\hline 19 & 9 & 81 \\
\hline 20 & 9 & 81 \\
\hline 21 & 8 & 64 \\
\hline 22 & 9 & 81 \\
\hline 23 & 8 & 64 \\
\hline 24 & 8 & 81 \\
\hline 25 & 8 & 64 \\
\hline
\end{tabular}




\begin{tabular}{|c|c|c|}
\hline $\mathrm{N}$ & $\mathrm{T} 1$ & $\mathrm{~T} 2$ \\
\hline 26 & 9 & 81 \\
\hline 27 & 9 & 81 \\
\hline 28 & 8 & 64 \\
\hline 29 & 9 & 81 \\
\hline 30 & 9 & 81 \\
\hline$\sum$ & 246 & 2032 \\
\hline
\end{tabular}

Standard Deviation (S1)

$$
\begin{aligned}
& S 1=\sqrt{\frac{n \cdot \Sigma X^{2}-(\Sigma X)^{2}}{n(n-1)}} \\
& S 1=\sqrt{\frac{30.2032-(246)^{2}}{30(30-1)}} \\
& S 1=\sqrt{\frac{60960-60516}{30.29}} \\
& S 1=\sqrt{\frac{444}{870}} \\
& S 1=\sqrt{0,51} \\
& S 1=0.71
\end{aligned}
$$

The result of the analysis shows the following fact. There aere thirty (30) students took part in the test. Of these thirty (30) students in otre-test the highest score was eight (8) was achieved by five (5) students. The lowest score was six (6), was achieved by fourteen (14) students and eleven (11) students got score seven (7). In post-test the highest score was nine (9) was achieved by eleven(11) students, score eight (8) was achieved by fourteen (14) and five (5) students got score seven (7).

The mean score of the pre-test $\left(\mathbf{x}_{1}\right)$ is 6,7 and the mean score of post-test $\left(\mathbf{x}_{2}\right)$ is 8,2 . It can be said that the result of post-test is much better than the pre-test.

The result of pre-test indicates that the students' ability in speaking is still low befiore applying the treatment of small group discussion technique. The result of post-test indicates that the students' ability in speaking is increased. 
Journal of Educational Method and Technology Vol. 2 No. 3, Desember 2019

P-ISSN 2622-8459 E-ISSN 2622-8467

http://ejournal.unima.ac.id/index.php/jemtec

Based on the description above it can be concluded that the hypothesis is accepted because the score of post-test is higher than that of pre-test. It also shows that the small group discussion technique is effective to increase students' speaking ability.

\section{Conclusion and Suggestion}

\section{Conclusion}

1) The result of this research shows that the mean score in the post-test $(8,2)$ is higher than the pre-test $(6,7)$. It means that the speaking ability of the students is improved.

2) Small group discussion technique can give significant influence in improving students spaking ability.

3) Teaching speaking by using small group discussion technique makes the students learn more active.

\section{Suggestion}

1) English teacher are suggested to apply and develop this technique in teaching speaking in order to make the teaching learning process more effective and enjoyable.

2) Students should be provided with a lot of time to practice speaking English.

3) It will be better for the English teacher to vary the technique of teaching to avoid the boredom that might appear to the students.

\section{References}

Brown, H.D. 1979. Principle of 1Earning and Teaching . New Jersey: Prentice Hall, Inc.

Clark, L.H and Starr, L.S. 1981. Secondary and Middle School Teaching Methods. New York : McMillan Publisher Co.Inc.

Cobuils, Collins . 1987. English Language Dictionary. Collins. Birmingham University International Database English.

Gay, L.R. 1981. Educational Research. Colombus: Charles E. Merril Co.

Hatch and Farhady. 1982. Research Design and Statistics for Applied Linguistics. Massachusetts: Newbury House Publisher.

Hopson, B and Scally, M. 1981. Lifeskill Teaching . England: McGraw-HillBook Company.

Kasihani, K.S dkk . 2002. Communicative English in Context. Bandung: Grafindo Media Pranata.

Lado, R. 1977. Language Testing: The Sonstructional and Use of Foreign Test. London. Longam Group Ltd.

Lubis, Y. 1988. Developing Communicative Proficiency in the English as a Foreign Language (EFL) Class. Jakarta: Depdikbud. 